\title{
Efek Pemberian Suplemen Kurkumin serta Serbuk Kunyit terhadap Kadar Protein Daging dan Bobot Karkas Puyuh Jepang (Coturnix coturnix japonica)
}

\section{The Effects of Supplementing Curcumin and Turmeric Powder on Protein Levels and Weight of Japanese Quail Carcasses (Coturnix coturnix japonica)}

\author{
Fransisca Natalia Avianti, Tyas Rini Saraswati*, Silvana Tana \\ Program Studi Biologi, Departemen Biologi, Fakultas Sains dan Matematika, Universitas Diponegoro \\ *Email: tyasrinis63@gmail.com
}

Diterima 19 Juni 2020/Disetujui 29 Agustus 2020

\begin{abstract}
ABSTRAK
Penelitian ini bertujuan untuk menganalisis kadar protein daging dan bobot karkas puyuh jepang (Coturnix coturnix japonica) setelah diberi suplemen kurkumin serta serbuk kunyit. Penelitian ini menggunakan metode eksperimental dengan Rancangan Acak Lengkap (RAL). Hewan uji yang digunakan sebanyak 24 ekor puyuh jepang yang dibagi dalam 3 perlakuan yang terdiri dari P0: puyuh jepang yang tidak diberi suplemen kurkumin maupun kunyit (kontrol), P1: puyuh jepang yang diberi suplemen kurkumin kasar 0,15 mg/ekor, dan P2: puyuh jepang yang diberi serbuk kunyit kadar 108 mg/ekor. Parameter yang diamati yaitu konsumsi pakan, konsumsi minum, kadar protein daging dan bobot karkas. Data yang diperoleh, dianalisis menggunakan ANOVA kemudian dilanjutkan dengan uji Duncan Multiple Range Test pada taraf kepercayaan 95\%. Hasil analisis data menunjukkan bahwa pemberian suplemen kurkumin serta serbuk kunyit memberikan pengaruh nyata terhadap peningkatan kadar protein daging, namun tidak memberikan pengaruh nyata terhadap peningkatan konsumsi pakan, konsumsi minum dan bobot karkas puyuh jepang. Berdasarkan penelitian ini disimpulkan bahwa pemberian suplemen kurkumin serta kunyit pada puyuh jepang (Coturnix coturnix japonica) dapat meningkatkan metabolisme protein sehingga kadar protein daging meningkat dan mendukung performa puyuh jepang.
\end{abstract}

Kata kunci: puyuh jepang, kurkumin, serbuk kunyit

\begin{abstract}
This study aimed to analyze the meat protein content and weight of Japanese quail carcass (Coturnix coturnix japonica) after being supplemented with curcumin and turmeric powder. This study used an experimental method with Completely Randomized Design (CRD) and used were 24 Japanese quails which were divided into 3 treatments consisting of P0: Japanese quails that were not given suplement (control), P1: Japanese quails that were given curcumin supplements levels $0.15 \mathrm{mg}$ / head, and P2 : Japanese quail given turmeric powder levels of $108 \mathrm{mg} /$ head. The parameters observed were feed consumption, drinking consumption, meat protein content and carcass weight. The data obtained were analyzed with ANOVA then continued with Duncan Multiple Range Test at $95 \%$ confidence level. The results showed that supplementation of curcumin and turmeric powder had a significant effect on increasing levels of meat protein, but did not have a significant effect on increasing of feed consumption, drinking consumption and weight of Japanese quail carcass. Based on this study, it was concluded that supplementation of curcumin and turmeric in Japanese quail (Coturnix coturnix japonica) can increase protein metabolism so that meat protein levels increased and supported the body's performance in early growth of Japanese quail.
\end{abstract}

Keywords: Japanese quail, curcumin, turmeric powder 


\section{PENDAHULUAN}

Puyuh jepang (Coturnix coturnix japonica) merupakan salah satu sumber protein hewani dengan produktivitas yang tinggi, mudah beradaptasi terhadap iklim tropis, manajemen pemeliharaan yang mudah serta matang kelamin pada usia 42 hari (Tuleun \& Dashe, 2010). Kematangan seksual puyuh jepang berhubungan dengan performa tubuh yang baik melalui tercapainya bobot badan yang optimal pada fase awal pertumbuhan puyuh jepang (starter) (Utomo dkk., 2014). Bobot badan berkaitan dengan pertumbuhan otot yang terjadi melalui penambahan sarkomer baru sehingga untuk menambah bobot badan dan karakteristik serat otot, baik dipacu pada awal pertumbuhan agar meningkatkan kinerja puyuh Jepang (Choi et al., 2013). Kandungan kimiawi pada otot yakni yang terutama berupa protein selain itu berupa air, lemak, karbohidrat dan vitamin (Kartikayudha dkk., 2014).

Apabila fase awal pertumbuhan, puyuh jepang berada dalam kondisi optimal, maka akan tercapai performa biologis yang prima dan berbagai organ tubuh dapat bekerja dengan baik (Mone dkk., 2016). Perbedaan fase pertumbuhan pada puyuh menyebabkan adanya perbedaan kebutuhan zat pakan (Radhitya, 2015). Komposisi bahan pakan yang dikonsumsi oleh puyuh jepang pada masa pertumbuhan akan mempengaruhi pembentukan otot (Mazizi et al., 2020). Penelitian Widodo dkk., (2013) menyatakan bahwa protein merupakan salah satu komponen yang diperlukan pada pakan yang akan dicerna dan dimetabolisme untuk pembentukan otot sehingga secara langsung juga akan meningkatkan pertambahan berat badan harian $(\mathrm{PBBH})$.

Kunyit merupakan tanaman rimpang yang termasuk salah satu suku tanaman temu-temuan (Zingiberaceae). Senyawa kimia utama yang terkandung pada kunyit yakni minyak atsiri dan kurkuminoid. Komponen aktif yang banyak terkandung pada kunyit ialah kurkuminoid yang meliputi $\quad 71,5 \% \quad$ kurkumin, $19,4 \%$ demetoksikurkumin dan $\quad 9,4 \quad \%$ bisdemetoksikurkumin (Sabale et al., 2013) Penelitian Saraswati \& Tana (2016) menunjukkan bahwa pemberian dosis kunyit hingga 108 mg/ekor/hari dapat memberikan pengaruh yang maksimal terhadap kematangan seksual yang lebih cepat serta dapat meningkatkan kualitas kimia telur puyuh jepang. Menurut Pratikno (2011), kurkumin dapat meningkatkan aktivitas saluran pencernaan dengan cara mempengaruhi penyerapan nutrisi dan memperlancar pengeluaran empedu. Kurkumin pada kunyit dapat merangsang dinding kantong empedu mengeluarkan cairan empedu dan merangsang keluarnya getah pankreas yang mengandung enzim amilase, lipase, dan protease yang berguna untuk meningkatkan pemecahan lemak dan protein. Penelitian sebelumnya oleh Hossen et al., (2010) menyatakan bahwa suplementasi kunyit dapat meningkatkan berat badan puyuh jepang setiap minggu dibandingkan dengan kelompok kontrol. Penelitian Kartikayudha dkk., (2014) menunjukkan terdapat pengaruh tepung kunyit dalam proses pembentukan protein otot menjadi meningkat seiring meningkatnya kualitas ransum, sehingga kadar protein kasar daging puyuh baik pada pektorales maupun femorales dapat meningkat. Menurut Widyastuti dkk., (2014) kandungan senyawa kurkuminoid dan minyak atsiri pada kunyit dapat membantu proses metabolisme enzimatis pada puyuh jepang sehingga juga dapat memperbaiki metabolisme nutrien.

\section{METODE PENELITIAN}

Penelitian ini dilaksanakan di kandang penelitian Laboratorium Biologi Struktur dan Fungsi Hewan Departemen Biologi Fakultas Sains dan Matematika Universitas Diponegoro selama 4 bulan. Alat-alat yang digunakan dalam penelitian ini berupa sprayer, 3 set kandang, timbangan analitik, timbangan digital, gelas ukur, wadah makan dan minum, kertas koran, bohlam 15 watt, bak parafin, satu set alat bedah, labu kjedahl, labu erlenmeyer, mortar, alu, pipet tetes, pemanas kjedahl, buret, gelas kimia, alat distilasi dan labu ukur. Bahan yang digunakan adalah rhodalon cair, 50 ekor puyuh jepang (Coturnix coturnix japonica) betina, vaksin ND II, air minum, pakan komersial (B-82 P), vitamin (Vitachick), kunyit, kurkumin, aluminium foil, $\mathrm{CuSO}_{4}, \mathrm{H}_{2} \mathrm{SO}_{4}, \mathrm{H}_{3} \mathrm{BO}_{3}, \mathrm{NaOH}$, metil merah, $\mathrm{HCl}$ dan aquadest. Penelitian ini menggunakan desain Rancangan Acak Lengkap 
(RAL), dengan parameter penelitian meliputi kadar protein daging, bobot karkas, konsumsi pakan dan minum harian puyuh jepang (Coturnix coturnix japonica). Sampel penelitian yang digunakan sebanyak 24 ekor puyuh jepang betina (Coturnix coturnix japonica) dengan bobot seragam yang dibagi ke dalam 3 kelompok perlakuan. Masingmasing kelompok perlakuan dilakukan 8 kali pengulangan. Pemberian perlakuan pada masingmasing perlakuan yaitu sebagai berikut :

P0 : kontrol atau tanpa perlakuan.

P1 : diberi suplemen kurkumin kadar 0.15 $\mathrm{mg} / \mathrm{ekor} / \mathrm{hari}$.

P2: diberi serbuk kunyit kadar 108 $\mathrm{mg}$ /ekor/hari.

Cara kerja meliputi persiapan kandang dan persiapan hewan uji. Kandang yang digunakan berukuran $80 \mathrm{~cm} \mathrm{X} 80 \mathrm{~cm} \mathrm{X} 40 \mathrm{~cm}$. Kandang disikat dan disterilisasi dengan rhodalon cair yang disemprotkan menggunakan sprayer, kemudian dipasang lampu bohlam $15 \mathrm{~W}$ dan pada bagian bawah kandang di beri alas berupa kertas koran untuk menampung kotoran. Persiapan hewan uji dilakukan dengan melakukan aklimatisasi lima puluh ekor puyuh jepang berumur 8 selama 1 minggu. Puyuh di berikan vitamin (Vitachick) dan pada umur 14 hari puyuh diberikan vaksin ND2 melalui tetes mata sebagai stimulasi antibodi puyuh. Puyuh jepang ditimbang berat badannya, lalu dipilih individu puyuh jepang yang memiliki berat badan seragam sebesar \pm 40 g sebanyak 24 ekor, kemudian dikelompokkan ke dalam 3 kelompok perlakuan.

Pakan dan minum diberikan secara ad libitum. Perlakuan diberikan melalui air minum selama 60 hari dengan dosis kunyit $108 \mathrm{mg} /$ ekor atau $0.108 \mathrm{~g} /$ ekor (Saraswati \& Tana, 2016) dan dosis kurkumin yang digunakan yakni sebesar 0.15 mg. Pakan yang diberikan kepada semua kelompok perlakuan yakni pakan komersial (B-82 P).

Perhitungan kadar protein dalam daging ditentukan dengan metode Kjeldahl melalui tiga tahap yakni destruksi sampel, destilasi, dan titrasi. Sampel yang digunakan sebanyak $1 \mathrm{~g}$ lalu dihaluskan, dimasukkan dalam labu Kjeldahl ditambahkan $\mathrm{CuSO}_{4}$ sebagai katalis dan $10 \mathrm{ml}$ $\mathrm{H}_{2} \mathrm{SO}_{4}$ pekat. Labu kjehdal bersama isinya digoyangkan sampai semua sampel terbasahi dengan $\mathrm{H}_{2} \mathrm{SO}_{4}$ pekat kemudian sampel dipanaskan selama 15 menit hingga jernih. Sampel didestruksi lalu didinginkan kemudian dituang dalam labu ukur $100 \mathrm{ml}$ dan bilas dengan air suling. Sampel ditambahkan $\mathrm{NaOH}$ kemudian didestilasi dengan $10 \mathrm{ml} \mathrm{H}_{3} \mathrm{BO}_{3}$ (asam borat) 2\%. Sampel ditambahkan 4 tetes indikator metil merah dalam erlenmeyer dan dipipet $10 \mathrm{ml} \mathrm{NaOH} 30 \%$ dalam $100 \mathrm{ml}$ air suling kemudian disuling hingga volume penampung menjadi $\pm 50 \mathrm{ml}$. Bilas ujung penyuling 5-6 kali dengan air suling, sampel ditampung pada erlenmeyer dan isinya dititrasi dengan $\mathrm{HCl} 0,0103$ N. Perhitungan \% Protein dihitung menggunakan rumus :

$\%$ Protein $=\mathrm{N} . \mathrm{HCl} \times 14,008 \times 100 \%$ Keterangan $=\mathrm{N}$ : banyaknya HCL $(\mathrm{ml})$.

\section{HASIL DAN PEMBAHASAN}

Hasil analisis pengaruh pemberian perlakuan suplemen kurkumin serta serbuk kunyit terhadap konsumsi pakan, konsumsi minum, kadar protein daging dan bobot karkas puyuh jepang (Coturnix coturnix japonica) menggunakan uji Analysis of Variance (ANOVA) one way dan dilanjutkan uji Duncan Multiple Range Test dengan taraf kepercayaan 95\%, disajikan pada Tabel 4.1. Hasil analisis statistik menunjukkan bahwa pengaruh pemberian perlakuan suplemen kurkumin serta serbuk kunyit terhadap konsumsi pakan tidak berbeda nyata $(\mathrm{P}>0,05)$. Pemberian perlakuan suplemen kurkumin serta serbuk kunyit tidak mempengaruhi konsumsi pakan pada puyuh jepang. Penelitian Saraswati \& Tana (2016) menunjukkan bahwa pemberian kunyit dosis $108 \mathrm{mg} /$ ekor tidak memberikan pengaruh terhadap konsumsi pakan puyuh. Faktor yang berpengaruh terhadap konsumsi pakan adalah palatabilitas, lingkungan dan perilaku puyuh. Palatabilitas adalah tingkat kesukaan yang ditunjukkan suatu ternak terhadap pakan yang diberikan pada waktu tertentu. Penelitian Widyastuti dkk (2014) menujukkan bahwa konsumsi pakan tidak berbeda nyata $(\mathrm{P}>0,05)$ karena rasa yang pahit pada kunyit tidak mempengaruhi palatabilitas pada puyuh jepang. Faktor lingkungan pada penelitian ini tidak berpengaruh karena puyuh $\mathrm{P} 0, \mathrm{P} 1$ dan $\mathrm{P} 2$ dikondisikan pada lingkungan yang sama. Konsumsi pakan juga dipengaruhi oleh perilaku makan puyuh jepang. Perilaku makan pada puyuh jepang juga berhubungan dengan cara pemberian pakan. Pemberian pakan pada penelitian ini 
dilakukan secara ad libitum, sehingga tidak memberikan pengaruh nyata terhadap konsumsi pakan. Hal ini sesuai pendapat Tamba dkk., (2019) bahwa pemberian pakan puyuh lebih baik jika diberikan secara ad libitum dibandingkan pemberian pakan dengan dibatasi dalam jumlah dan waktu tertentu. Pembatasan ini mempengaruhi perilaku makan pada puyuh jepang, karena perilaku makan pada puyuh akan muncul saat unggas merasa lapar.

Tabel 1 Hasil analisis pemberian perlakuan suplemen kurkumin serta serbuk kunyit terhadap konsumsi pakan, konsumsi minum, kadar protein daging dan bobot karkas puyuh jepang (Coturnix coturnix japonica).

\begin{tabular}{lccc}
\hline & P0 & P1 & P2 \\
\hline Konsumsi Pakan $(\mathrm{g})$ & $33,22^{\mathrm{a}} \pm 17,20$ & $33,02^{\mathrm{a}} \pm 15,61$ & $33,60^{\mathrm{a}} \pm 16,31$ \\
Konsumsi Minum & $53,18^{\mathrm{a}} \pm 15,11$ & $65,31^{\mathrm{b}} \pm 19,07$ & $61,85^{\mathrm{b}} \pm 17,30$ \\
$(\mathrm{~mL})$ & & $17,73^{\mathrm{b}} \pm 0,46$ & $18,83^{\mathrm{c}} \pm 0,50$ \\
Kadar Protein & $16,85^{\mathrm{a}} \pm 0,40$ & $75,00^{\mathrm{a}} \pm 10,48$ & $78,33^{\mathrm{a}} \pm 7,52$ \\
Daging (\%) & $76.66^{\mathrm{a}} \pm 10,32$ & Bobot Karkas (g) & Keterangan : Superskrip sama pada baris yang sama menunjukkan perbedaan tidak nyata (P > \\
\multicolumn{2}{r}{ 0,05). P0 (kontrol), P1 (puyuh yang diberi perlakuan kurkumin 0,15 mg/ekor), dan } \\
P2 (puyuh yang diberi perlakuan serbuk kunyit 108 mg/ekor).
\end{tabular}

Hasil analisis statistik menunjukkan bahwa pengaruh pemberian perlakuan suplemen kurkumin serta serbuk kunyit terhadap konsumsi minum menunjukkan perbedaan nyata $(\mathrm{P}<0,05)$ antara kelompok puyuh kontrol (P0) dengan puyuh perlakuan $\mathrm{P} 1$ dan $\mathrm{P} 0$ dengan $\mathrm{P} 2$, namun tidak terdapat perbedaan yang nyata $(\mathrm{P}>0,05)$ antara kelompok puyuh perlakuan P1 dan P2. Penelitian ini menunjukkan bahwa baik pemberian suplemen kurkumin dan kunyit dapat meningkatkan konsumsi minum. Salah satu faktor yang mempengaruhi konsumsi minum yakni osmolaritas cairan. Osmolaritas cairan tubuh berkaitan dengan konsentrasi mineral yang pengaturannya dilakukan oleh ginjal. Iovino et al., (2012) menyatakan bahwa mekanisme kerja ginjal dalam pengaturan konsetrasi mineral tubuh melalui sekresi hormon vasopresin $(\mathrm{ADH})$. Hormon $\mathrm{ADH}$ diproduksi di retikulum endoplasma nukleus paraventrikular dan supraoptik hipotalamus dan disekresikan oleh hipofisis posterior. Setelah disekresikan, hormon ADH masuk ke dalam aliran darah dan akan berikatan dengan reseptor V2 yang terletak pada basolateral sel koligentes yang ada di ginjal. Menurut Kusumastuti dkk., (2012) apabila konsentrasi mineral meningkat di atas normal atau osmolaritas meningkat di atas normal, maka unggas merasa haus dan memerlukan minum, dan setelah minum, maka osmolaritas menurun kembali. Pemberian perlakuan suplemen kurkumin dan serbuk kunyit diduga dapat meningkatkan osmolaritas cairan tubuh puyuh jepang sehingga mempengaruhi kinerja ginjal. Hal ini sesuai penelitian Akbar \& Hari (2017), bahwa pada kunyit terdapat kandungan senyawa berupa kurkumin yang dapat berfungsi dalam memperlancar pencernaan dan minyak atsiri yang meningkatkan fungsi ginjal.

Hasil analisis statistik pengaruh pemberian perlakuan suplemen kurkumin serta serbuk kunyit terhadap kadar protein daging menunjukkan hasil yang berbeda nyata $(\mathrm{P}>0,05)$ antara puyuh $\mathrm{P} 0$ dan $\mathrm{P} 1, \mathrm{P} 0$ dan P2 serta P1 dan P2. Pemberian suplemen serbuk kunyit serta kurkumin menyebabkan kenaikan kadar protein daging puyuh jepang. Hal ini sesuai dengan penelitian Katikayudha dkk., (2014) bahwa terdapat pengaruh nyata yakni adanya kenaikan secara signifikan protein daging baik pada pektorales maupun femorales karena adanya pemberian serbuk kunyit yang mengandung senyawa p-tolymethylcarbinol yang memberikan pengaruh positif terhadap traktus gastrointestinal sehingga meningkatkan

sekresi enzim pankreatik. Pengaruh positif sekresi enzim pankreatik ini dapat meningkatkan proses digesti dan absorpsi serta metabolisme protein di dalam saluran pencernaan puyuh jepang, selain itu serbuk kunyit juga membantu dalam pembentukan 
protein di otot sehingga dapat meningkatkan kandungan protein daging. Penelitian Rifa'i dkk., (2016) juga menyatakan bahwa pemberian kunyit hingga kadar 108mg/ekor terhadap puyuh jepang dapat meningkatkan efisiensi penyerapan nutrisi khususnya protein di dalam sistem pencernaan.

Penelitian yang telah dilakukan menunjukkan hasil bahwa puyuh jepang perlakuan
P1 (kurkumin) dan P2 (serbuk kunyit) menunjukkan adanya kenaikan kadar protein daging dibandingkan dengan P0 (kontrol). Kadar protein daging puyuh secara berurut-turut $\mathrm{P} 0, \mathrm{P} 1$ dan P2 yakni sebesar 16, 85\%, 17,7\% dan 18,83\% yang dapat dilihat pada Gambar 1

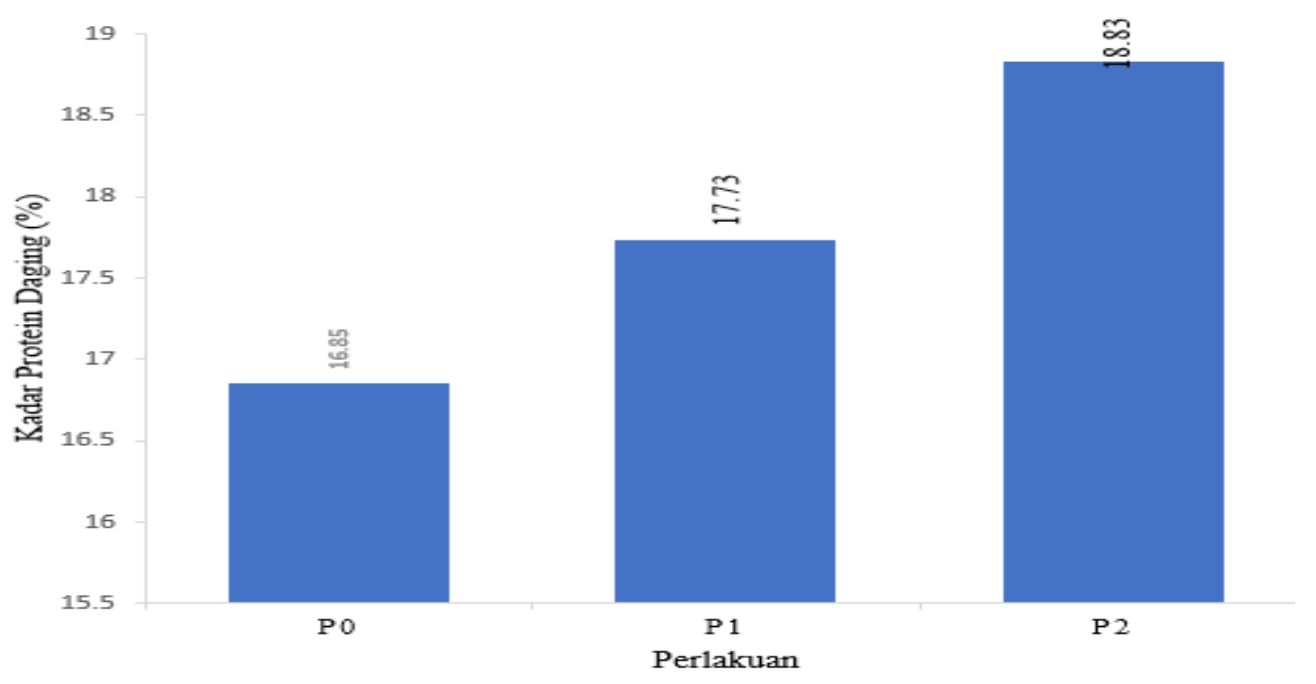

Gambar 1. Diagram Batang Pengaruh Pemberian Suplemen kurkumin dan serbuk kunyit terhadap Kadar Protein Daging Puyuh Jepang

Kenaikan lebih tinggi kadar protein daging terlihat pada puyuh perlakuan P2 (serbuk kunyit) yakni sebesar $18,83 \%$. Kenaikan kadar protein daging lebih tinggi pada perlakuan kunyit diduga karena pemberian kunyit selain terdapat kurkumin terdapat pula kandungan senyawa lain seperti minyak atsiri yang membantu kinerja penyerapan nutrisi. Muliani (2015) menyatakan bahwa dalam kunyit terdapat kandungan minyak atsiri yang berfungsi mengatur asam lambung $(\mathrm{HCl})$ agar tidak berlebihan dan tidak kekurangan. Asam lambung berguna untuk mengaktifkan pepsinogen menjadi pepsin. Apabila pengaturan sekresi asam lambung dan pepsin yang semakin baik maka proses pencernaan, khususnya penyerapan zat-zat makanan serta pemecahan protein semakin baik yang berpengaruh pada metabolisme protein dalam tubuh.
Hasil analisis pengaruh pemberian perlakuan suplemen serbuk kunyit terhadap bobot karkas menunjukkan hasil yang tidak berbeda nyata $(\mathrm{P}>0,05)$. Pemberian perlakuan suplemen kurkumin dan serbuk kunyit tidak mempengaruhi kenaikan bobot karkas pada puyuh jepang. Penelitian Kinaly \& Mahmoud (2014) menunjukkan bahwa pemberian kunyit tidak memberikan hasil yang siginifikan pada pertambahan bobot karkas. Selain itu pada penelitian puyuh sudah memasuki masa bertelur, sehingga energi lebih banyak digunakan untuk pembentukan telur (produksi) dibandingkan untuk peningkatan bobot tubuh. Penelitian Rifa'i dkk., (2016) menunjukkan bahwa pemberian suplemen kunyit hingga kadar 108mg/ekor menunjukkan hasil yang tidak berbeda nyata $(\mathrm{P}>$ $0,05)$ terhadap kenaikan bobot badan karena puyuh berada dalam fase bertelur, sehingga energi lebih 
banyak dimanfaatkan untuk bertelur dibandingkan untuk pembentukan tubuh.

\section{KESIMPULAN}

Pemberian suplemen kurkumin serta kunyit pada puyuh jepang (Coturnix coturnix japonica) dapat meningkatkan metabolisme protein sehingga kadar protein daging meningkat dan mendukung performa tubuh awal pertumbuhan puyuh jepang.

\section{UCAPAN TERIMAKASIH}

Ucapan terima kasih penulis sampaikan kepada pembimbing skripsi yang telah melibatkan penelitian yang di danai LPPM Undip melalui dana Riset Pengembangan dan Penerapan Tahun Anggaran 2019.

\section{DAFTAR PUSTAKA}

Akbar, M. \& Hari, M.E. 2017. "Pengaruh Pemberian Kunyit (Curcuma longa $\mathrm{L}$ ) dan Temulawak (Roxb) Dalam Air minum terhadap Performa Puyuh Jantan." Jurnal Fillia Cendekia 2 (2): 8-16.

Choi, Y. M., Shin, S., Wick, M. P., Choe, J. H., \& Lee, K. 2013. "Muscle fiber characteristics of pectoralis major muscle as related to muscle mass in different Japanese quail lines". Animal, 7(10), 1665-1670

Hossen, S., Rakibul I., Fahima B.A, Moehammad. M.H. \& Misrat M.P. 2018. "Effects of Turmeric paste on Growth Performance, Immune response and Blood characteristics in Japanese Quail." International Journal of Science and Business 2(3): 306-317.

Iovino, M., Eduardo, G., Vito, A.G., Brunella L and Vincenzo, T. 2012. . "Vasopressin Secretion Control: Central Nautral Pathways, Neurotransmitters and Effect of Drugs". Current Pharmaceurical Design 18: $4714-4724$.

Kartikayudha, W., Isroli. \& Suprapti, N.H. 2014. "Kadar Protein dan Bobot Daging Puyuh Setelah Pemberian Bahan Tambahan Pangan Pakan Tepung Ikan Swangi dan Peridiosasi Waktu Pemberian Tepung Kunyit yang Berbeda Pada Ransum."
Buletin Anatomi dan Fisiologi 22(1): 1729.

Kilany O.E., \& Mahmoud, M. M. A. 2014. "Turmeric and Exogenous Enzyme Supplementation Improve Growth Performance and Immune Status of Japanese quail". World's Veterinery Journal 4(3): 20-29.

Kusumastuti, D.T., Praseno, K. \& Saraswati, T.R. 2012. "Indeks Kuning Telur dan Nilai Haugh Unit Telur Puyuh (Coturnix coturnix japonica L.) Setelah Pemberian Tepung Kunyit (Curcuma longa L.)." Jurnal Biologi 1(1): 15-22.

Mazizi, B. E., Erlwanger, K. H., \& Chivandi, E. (2020). The effect of dietary Marula nut meal on the physical properties, proximate and fatty acid content of Japanese quail meat. Veterinary and Animal Science, 9, 100096.

Mone, D. A. W., Sudjarwo, E., \& Muharlien. 2016. " Pengaruh Jenis Burung Puyuh (Coturnix coturnix japonica) Dengan Pemberian Pakan Komersial yang Berbeda terhadap Penampilan Produksi Periode Bertelur". Jurnal Ternak Tropika 17(2): 43 - 49.

Radhitya, A. 2015. "Pengaruh Pemberian Tingkat Protein Ransum pada Fase Grower terhadap Pertumbuhan Puyuh (Coturnix coturnix japonica)." Students E-journals $4(1)$.

Rifa'i, A., Saraswati, T.R. \& Tana, S. 2016. "Kadar Protein Daging Pada Keturunan Puyuh (Coturnix Dari Induk Yang Diberi Suplemen Serbuk Kunyit Dalam Pakan." BIOMA 18(2): 97-101.

Sabale, P., Arjun, M., \& Vidya, S. 2013. "Curcuma longa Linn. A Phytochemical and Phytopharmacological". Journal of Pharmacognosy and Phytochemistry 5 (2): 59-68

Saraswati, T.R. \& Tana, S. 2016. "Effect of Turmeric Powder Supplementation to The Age of Sexual Maturity, Physical, and Chemical Quality of The First Japanese 
Quail's (Coturnix coturnix japonica) Egg." Biosintifika 8(1): 18-24.

Sugiharto., Isroli., Widiastuti, E., \& Prabowo, N.S. 2017. "Effect of turmeric extract on blood parameters, feed efficiency and abdominal fat content in broilers." Journal Indonesian Tropical Animal Agriculture 36(1): 21-26

Tamba, H. R., Atmomarsono, E. \& Suprijatna U. 2019. "Pengaruh Frekuensi dan Periode Pemberian Pakan yang Berbeda terhadap Tingkah Laku Makan Burung Puyuh Petelur." Jurnal Sains Sains Peternakan Indonesia 14(1): 28-37.

Tuleun, C.D \& Dashe, N.A . 2010. "Effect of Dietery Levels of Toasted Mucuna Seed Meal (TMSM) on Performance and Egg Quality Parameters of Laying Japanese Quails (Coturnix coturnix japonica)." International Journal Poultry Science 1092-1096.

Utomo, J.W., Sudjarwo., E. \& Hamiyanti, A.A. 2014. "Pengaruh Penambahan Tepung Darah pada Pakan terhadap Konsumsi Pakan, Pertambahan Bobot Badan, Konversi Pakan Serta Umur Pertama Kali Bertelur Purung Puyuh." Jurnal Ilmu-Ilmu Peternakan 24 (2): 41 - 48.

Widodo, A. R., Setiawan, H., Sudiyono, S. \& Indreswari, R. 2013. "Kecernaan Nutrien dan Performan Puyuh (Coturnix coturnix japonica) Jantan yang Diberi Ampas Tahu Fermentasi dalam Ransum." Tropical Animal Husbandry 2(1): 51-57.

Widyastuti, W., Mardiati, S.M. \& Saraswati, T.R. 2014. "Pertumbuhan Puyuh (Coturnix coturnix japonica) setelah Pemberian Tepung Kunyit (Curcuma longa L.) pada Pakan." Buletin Anatomi dan Fisiologi 22(2): 12-20. 